\title{
Information Technology and the Cost of Bank Loans: An Empirical Investigation
}

\author{
Shu Han \\ Sy Syms School of Business \\ Yeshiva University \\ shan@yu.edu
}

\author{
Shameem Hasan \\ Ecole Polytechnique Fédérale de \\ Lausanne (EPFL), Switzerland \\ shasan@msn.com
}

\author{
Christopher Tucci \\ Ecole Polytechnique Fédérale de \\ Lausanne (EPFL), Switzerland \\ christopher.tucci@epfl.ch
}

\begin{abstract}
In this paper, we examine the effect of IT investment on the cost of bank loans for firms, drawing upon theories of banking and risk management. On one hand, IT may be able to reduce the risk of being overtaken by competition or other adverse situations; on the other hand, the IT investment itself might be considered risky due to nature of the digital transformation. Using a sample of 261 firms from 1991-2006 and data from InformationWeek, DealScan and Compustat, we find that IT investment is associated with lower interest rates from banks. More importantly, we find the strength of this relationship is contingent upon the role of IT in the industry, the intensity of competition in the industry, and whether the firm is diversified.
\end{abstract}

\section{Introduction}

Business and Strategy researchers have long been interested in the links between investment in Information Technology (IT) and firm performance. Over time, it has been found that IT investment is associated with superior firm performance, measured by productivity [1] [2] [3], profitability [4], or growth potential [5]. As IT plays an increasingly important role in firm strategy and operations, external institutions such as equity investors, banks, and bondholders are also paying attention to IT investment of firms [6]. Previous research find that the stock market responds positively to the news of IT investment in general [7] [8]. Few papers, however, have investigated how debt holders respond to IT investment with the exception of Kim et al. (2017) [9] who examine the response of the bond market to IT investment. The ability to raise capital is critical to the existence of any business; and firm performance is not necessarily a result of only asset management, but also liability management. Hence, there is a need for a systematic analysis to understand the impact of IT on the financing side of firm strategy and policy. We aim to fill this gap in the literature by examining the effect of IT on the cost of bank loans.

Kim et al. (2017) [9] examines how IT influences the price of bond debt and finds that the effect of IT on bond ratings is different across different industries, although they did not find that IT has a significant effect on bond ratings in general. Banks are different from bondholders in the sense that bond lenders are arm-length lenders, and banks are considered quasi-insiders because they are sometimes given proprietary information that is not available to dispersed bondholders, such as the IT budget and the type of IT projects that are or will be undertaken [10] [11]. By examining the effect of IT on costs of bank loan, we hope to identify a clearer and more immediate effect of IT on the costs of financing.

Drawing upon risk management theories and using a sample of 261 companies over 15 years, we test whether higher IT investments are associated with lower interest rates. In addition, we test subhypotheses on how industry and firm characteristics influence the relationship between IT and cost of loans. This paper contributes to literature on IT business value in the following aspects. First, we demonstrate a new route or perspective in explaining the relationship between IT and profitability-by reducing costs of capital. More importantly, our findings show striking differences compared to those of Kim et al. (2017) [9], showing that banks respond very differently (almost the opposite) to IT investment compared with bond markets. Hence, our research helps to provide a more complete picture of how debt markets respond to IT investments and demonstrate that different lenders may perceive IT investment very differently due to their own risk preferences. Last, the paper has important 
implications for practitioners. Despite the abundance of research in IT business value, it is still difficult for CIOs (Chief Information Officers) to justify IT budgets to other executives and IT budgets are often cut during economic downturns due partially to the difficulties in measuring the impact of IT directly. Our results may help CIOs to justify IT budgets through a different angle.

The paper proceeds as follows. We first describe related literatures and develop hypotheses, followed by the introduction of data sources and measurement of variables. We then report the results. Finally, we discuss the implications of the results.

\section{Related Literature and Hypothesis Development}

Finance literature posits that the cost of debt is mostly determined by the risk of default. Evaluating the strategy of borrowing firms is essential to assess their risk of default. IT strategy or digital strategy has become an integral component of any firm's overall strategy, and thus may affect banks' evaluation of risk.

IT investment can be considered an option for future opportunities, which can reduce the riskiness or uncertainty in business [12]. In modern business, new business processes, products, or services often require the support of information technology. It is widely accepted that IT can facilitate innovation [13] [14]. For instance, innovations such as Amazon's One-Click Checkout process, Chase's mobile banking application, and inventory management from Walmart, are all enabled by information technologies. Firms with greater IT investment are more likely to be able to develop these applications and capabilities quickly to initiate innovation or respond to competitors' innovation by providing similar products/services. Thus, the risk of being locked out of competition due to lack of technologies can be reduced by IT investment. Second, due to network externalities, one major innovation could lead to a winner-take-all situation. For instance, the loss of customers from Myspace to Facebook was almost an overnight phenomenon. Customers tend to move from one digital platform to another rather rapidly. The network effects amplify the risk of being locked out due to lack of technology support. Last, IT investment can also reduce the risk of potential negative outcomes, such as website breakdowns and security breaches. In e-business, due to seasonal effects the number of transactions fluctuate throughout the year. Sometimes, the capacity of the IT infrastructure is sufficient in processing day-to-day business, but could come short during holidays such as before Christmas, leading to a services interruption. Such interruptions will negatively affect customers' experiences and risk losing their loyalty. More importantly, security breaches, such as exposing personal information of customers to hackers, poses a significant risk to the firm. It is found that stock market responds negatively to the news of security breaches. Such breaches may lead to potential litigation, which may impose fines and litigation costs on firms. On the whole, firms with greater IT investment are less vulnerable to adverse business situations, being locked out of competition, and to losing the trust of customers. Thus, banks will consider their business less risky and are more likely to provide them loans with better terms.

On the other hand, while IT investment promises potential high returns, it also involves high risk. Dewan and Ren (2011)[15] found that risk increases with the returns to IT, especially for firms in industries where IT has a transformative role. The risk of IT projects comes from two sources. First, implementation of IT systems is often accompanied with changes in business processes, organization structure, or human behavior. Such changes are prone to setbacks and failure[16]. Second, the competitive advantage achieved by IT investment could be temporary because competitors sometimes could imitate the business practice fairly quickly, which makes the IT-innovation a necessity[17].

On the whole, the effect of IT on firms' risk is ambiguous, and depends on the extent to which IT can reduce business risk vs. the extent to which IT brings new risk. Hence, we will test the empirical relationship without forming a formal hypothesis.

The business value of IT is often contingent upon the industry environment in which firms operate [18]. As a quasi-insider, banks are likely to evaluate the risk of IT investments based on the industry environment in which firms operate. Following Chatterjee et al. (2002) [8], we divide our sample into three industry groups based on the role IT plays in the industry: automate, informate, and transform. In automate industries, IT is simply used to replace humans to increase efficiency; in informate industries, IT is used to generate information that is used to enhance efficiency and effectiveness of the operations; in transform industries, IT completely changes the old business model. We did adjust 
Chatterjee et al. (2002)'s categorization by changing healthcare services to transform group ${ }^{1}$.

In transform industries, the risk of being locked out of competition and even being driven out of business due to lack of IT investment is particularly high. For instance, the demise of Blockbuster, Borders, and the Chicago Tribune is caused by their failure to provide digital platforms. In transform industries, IT is likely to be part of the core offering or a key enabler of the core offering of the firm. Thus, the occurrence of a website breakdown or security breach is particularly detrimental to firms in transform industries. Moreover, the effect of network externalities is particularly strong in transform industries because a digital platform is usually present, such as the firms providing e-trading or social networking platforms. In automate or informate industries, IT investment can help, but its role is probably not as critical as in transform industries. The network effect is likely to be lower and the adverse effect of IT issues is probably limited because IT is most likely not directly related to the core offering of firms. On the whole, the risk due to lack of IT investment in transform industries is much more prominent than in informate industries, and also more than in automate industries.

Regarding the risk associated with IT investments, in transform industries, because IT is used to change the business model completely, it probably brings radical change to routines, organizational structure and personnel in the meantime, making it most prone to resistance and failure and thus risky. However, the increase of ITrelated risk (from automate, to informate, and to transform industries) is probably flatter than the decrease of business risk by investing in IT (from automate to informate, and to transform). In transform industries, the risk caused by lack of IT investment is so high that it can easily outweigh the risk brought by investing in IT. In automate industries, the risk of lacking IT investment may be comparable to the risk brought by IT investment because firms may be able to find other ways to compete. Overall, we believe that the effect of IT investment on reducing firm risk is strongest for firms in transform industries and weakest for firms in automate industries.

H1: The effect of IT investment on loan spread is strongest for firms in transform industries and weakest for firms in automate industries (transform $>$ informate $>$ automate).

\footnotetext{
${ }^{1}$ We plan to use two different categorization schemes for the years dated before 2000 and after 2000 .
}

Below we classify industries based on twodigit SIC codes. Detailed industry classification information is shown footnote $2^{2}$.

Insert Table 1 here

\section{Data}

IT investment data were obtained from surveys published by InformationWeek from 1991 to 2006. The sample covers all firms for which we could collect data on IT investments during the period 1991-2005 (1997 and 1998 data are missing because the survey was not done for those two years). Firm-specific control variables were obtained from Compustat. The details of bank loan data were obtained from the Dealscan database provided by Loan Pricing Corporation. The final sample includes 261 firms with 1039 loans.

To test the effect of IT investment on cost of loan, we estimate the following equation:

Loan Spread $_{i, t}=a_{0}+b_{1}$ IT investment ratio ${ }_{i, t-1}+b_{2}$ firm-specific control variables $i_{i,-1}+$ b3 loan-specific

\footnotetext{
${ }^{2}$ Automate: Agriculture; Metal Mining; Coal Mining; Oil and Gas Extraction; Industrial and Commercial Machinery And Computer Equipment; Railroad Transportation; Motor Freight Transportation and Warehousing; Water transportation; Railcar leasing; Electric, Gas, And Sanitary Services; Amusement And Recreation Services. Informate: Apparel and Accessory Stores; Building Construction General Contractors And Operative Builders; Heavy Construction Other Than Building Construction Contractors; Construction Special Trade Contractors; Food And Kindred Products; Textile Mill Products; Apparel and Other Finished Products Made From Fabrics And Similar Materials; Lumber and Wood Products, Except Furniture; Furniture and Fixtures; Paper and Allied Products; Chemicals and Allied Products; Petroleum Refining and Related Industries; Rubber and Miscellaneous Plastics Products; Stone, Clay, Glass, and Concrete Products; Primary Metal Industries; Fabricated Metal Products, Except Machinery and Transportation Equipment; Electronic and Other Electrical Equipment and Components, Except Computer Equipment; Transportation Equipment; Measuring, Analyzing, and Controlling Instruments; Photographic, Medical and Optical Goods; Watches and Clocks; Miscellaneous Manufacturing Industries; Wholesale Trade-durable Goods; Wholesale Trade-non-durable Goods; Building Materials, Hardware, Garden Supply, and Mobile Home Dealers; General Merchandise Stores; Food Stores; Automotive Dealers and Gasoline Service Stations; Home Furniture, Furnishings, and Equipment Stores; Eating and Drinking Places; Miscellaneous Retail; Insurance Carriers; Hotels, Rooming Houses, Camps, And Other Lodging Places; Personal Services; Automotive Repair, Services, and Parking.

Transform: Printing, Publishing, and Allied Industries; Transportation by Air; Communications; Depository Institutions; Non-depository Credit Institutions; Security and Commodity Brokers, Dealers, Exchanges, and Services; Insurance Agents, Brokers, and Service; Holding and Other Investment Offices; Business Services; Health Services; Engineering, Accounting, Research, Management, and Related Services
} 
control variables $i, t+$ industry dummies + year dummies $+e_{i, t}$

where loan spread is the all-in-spread drawn over LIBOR for each loan facility as reported on Dealscan. IT investment ratio is firm IT investment divided by their asset, lagged by one year from the dependent variable. As the year of the loan from Dealscan database is the active date of the loan instead of the year when loan contract is signed, it is probably safer to use IT investment from previous year. Similar research has applied one-year lag when examining the effect of firm environment risk management practice and cost of loan[19] $]^{3}$. We control for both firm and loan specific characteristics. Firm specific controls include Asset (natural logarithm of a firm's total assets), Leverage (ratio of long-term debt to total assets), Profitability (ratio of earnings before interest, tax, depreciation and amortization divided by total assets), Growth Opportunity (the end of the previous year's market value of equity scaled by the prior fiscal year's book value), Current Ratio (the difference between current assets and inventories divided by current liabilities), risk (modified $\mathrm{z}$ score) and accounting quality (Absolute value of Jones (1991) measure of discretionary accruals). Firm specific controls are lagged by one year.

Strahan (1999)[20] argues that non-priceterms of loan contracts may affect loan spread, too, thus we control for loan characteristics, including logarithm of facility amount, logarithm of facility maturity, number of lenders, whether it involves performance pricing clause, whether collateral is required, number of financial covenants and number of lenders.

Year dummies and industry dummies (SIC2 industry) are included in the model as well.

The summary statistics of the variables are shown in Table 1.

Insert Table 1 here

To account for the fact that we have multiple observations from the same firm, we used ordinary least square regression with robust standard errors clustered by firms.

\section{Results}

\footnotetext{
${ }^{3}$ We plan to include robustness check to test whether more than one year of lag is needed.
}

The main results are shown in Table 2. In the base model (column 1), IT investment is negatively associated with the interest rate $(p<0.01)$. To check the robustness of the results, we run firm fixed effect model and the results are similar.

Columns 2, 3, 4 show the regression result for three subsamples: automate, informate, and transform industries. The results demonstrate that for firms in automate industries, IT has no effect on the interest rate of bank loan $(p>0.1)$; for firms in informate industries the effect of IT on interest rate is significant $(p<0.05)$; and that for firms in transform industries the effect of IT is significant $(p<0.05)$. Hence, $\mathrm{H} 1$ is partially supported as we did not find difference between informate and transform industries.

Insert Table 2 here

\section{Post-hoc Analysis}

We conducted several additional analyses to further examine the contingencies under which IT affects the cost of bank loan.

First, we divide the sample into two subgroups at the median level of industry concentration. We used the market share from the top three firms in the sic 2 industry group to proxy industry concentration. The results (column 1 and 2 of Table 4) show that in industries with low competition, IT does not have any effect on cost of loan and in industries with high competition, IT reduces the cost of loan. In industries with high competition, because the risk of not investing in IT and being locked out of business opportunities is much higher, the effect of IT is much stronger. This result lends support to our proposal that the mechanism through which IT investment reduces costs of loan is by reducing future business risk.

Second, we divide our sample into two groups: firms with single business segment and multiple segments. The results (column 3 and 4 of Table 3) show that for non_diversified firms, IT has a significant impact on costs of bank loans while for diversified firms, effect of IT is not significant. It may be because for firms with multiple segments, the implementation of IT is more complicated with each segment having its own need, agenda and leadership, which leads to higher chance of failure and thus higher risk. This neutralize the effect of IT on reducing future business risk and that is why we do not see any overall effect of IT on costs of bank loan. 
This result is different from prior research that find the effect of IT on firm performance is stronger for diversified firms [21], indicating that the mechanism through which IT affects costs of financing is different from the mechanism through which IT affects the revenue or assets.

Insert Table 3 here

\section{Discussions and Implications}

As IT plays in increasingly important role in firm overall strategy, stakeholders of firms are paying more attention to firms' IT investment and strategy. Prior research has examined the response from stockholders and bondholders to IT investment. These stakeholders, however, are considered armslength with the firm. By focusing on the responses from banks that tend to have a closer relationship with the firm and thus know more information about the firm, we hope to capture a closer link between IT investment and response from external stakeholders.

Our results show that in general IT investment is associated with lower loan spread, indicating that banks perceive IT investment to be associated with lower default risk. Furthermore, we find that in transform industries, the effect of IT on loan spread is stronger than in informate industries, and also than in automate industries. Such results suggest that IT is considered to hold a critical role by the banks in transform industries that it outweighs the concerns of risk of IT investment, and that in automate industries, the role of IT is the least critical, thus not affecting how banks evaluate default risk.

\section{Conclusion}

This paper contributes to the line of research on IT business value by examining the effects of IT on cost of capital for firms. The ability to access capital is critical to business and our study shows that IT can contribute to higher profitability by reducing the costs of capital. Furthermore, as far as we know, our paper is the first one that investigates the response of banks to IT investment. Our results are almost opposite to those of Kim et al. (2017) [9] that examines the response of bondholders to IT investments. While our results show that the effect of IT on cost of loan is stronger in transform and informate industries than in automate industries, Kim et al's results show that the effects of IT on bond spread are stronger in automate industries than in informate and transform industries. The difference is probably due to the differences in how banks and bondholders operate and in their levels of risk tolerance. Engaging in relationship lending, banks take more efforts to get to know their borrowers and sometimes are given proprietary information while bondholders are usually kept at arm's length. Hence, banks may develop a better understanding of the risks caused by lack of IT investment better, especially form firms in transform and informate industries and in turn, are willing to reward firms in transform and informate industries who investment more intensively in IT with lower interest rate. Another explanation is that although in transform industries where the risk associated with IT investment is higher, banks may be able to tolerate such risk better as they can monitor the borrowing firms more closely and leverage other terms in the loan contract (such as covenants, collaterals and performance pricing) to mitigate the risks associated with IT investment, compared with bonder holders.

\section{Future Works}

We plan to explore ways to update our data beyond year of 2006 to more recent years. We expect the results to be similar or even stronger as IT continues to be an important component of firm overall strategy and success.

\section{References}

1. Brynjolfsson, E. The productivity paradox of information technology. Communication of the ACM, 36, 12 (1993), 66-77.

2. Harris, S., and Katz, J. Organizational performance and IT investment intensity in the insurance. Organization Science, 2, 3 (1991), 263-295.

3. Mahmood, M., and Mann, G. Special issue: Impacts of information technology investment on organizational performance. Journal of Management Information Systems, 16, 4 (2000), 3-10.

4. Hitt, L.M., and Brynjolfsson, E. Productivity, Business Profitability, and Consumer Surplus: Three Different Measures of Information Technology Value. MIS Quarterly, 20, 2 (1996), 121-142.

5. Bharadwaj, A.S., Bharadwaj, S.G., and Konsynski, B.R. Information technology effects on firm performance as measured by Tobin's Q. Management Science, 45, 7 (1999), 1008-1024.

6. Porter, M. Strategy and the Internet. Harvard Business Review, 2001, pp. 62-78.

7. Sabherwal, R., and Sabherwal, S. Knowledge Management Using Information Technology: Determinants of Short-Term Impact on Firm Value. Decision Sciences, 36, 4 (2005), 531-567.

8. Chatterjee, D., Pacini, C., and Sambamurthy, V. The stockholder-wealth and trading volume effects of Information-technology infrastructure investments. Journal of Management Information Systems, 19, 2 (2002), 7-42. 
9. Kim, K., Mithas, S., and Kimbrough, M. Information Technology Investments and Firm Risk Across Industries: Evidence from the Bond Market. MIS Quarterly, 41, 4 (2017), 1347-1367.

10. Bhattacharya, S., and Chiesa, G. Proprietary Information, Financial Intermediation, and Research Incentives. Journal of Financial Intermediation, 4, 4 (1995), 328-357.

11. Gross, A., and Roberts, G. The impact of corporate social responsibility on the cost of bank loans. Journal of Banking \& Finance, 35, 7 (2011), 1794-1810.

12. Ducan, N.B. Capturing flexibility of information technology infrastructure: A study of resource characteristics and their measure. Journal of Management Information Systems, 12, 2 (1995), 37-57.

13. Joshi, K.D., Chi, L., Datta, A., and Han, S. Changing the competitive landscape: Continuous innovation through IT-enabled knowledge capabilities. Information Systems Research, 21, 3 (2010), 472-495.

14. Ravichandran, T., Han, S., and Mithas, S. IT and Innovation: Mitigating diminishing returns to R\&D. Information Systems Research, 28, 4 (2017), 812-827.
15. Dewan, S., and Ren, F. Information Technology and Firm Boundaries: Impact on Firm Risk and Return Performance. Information Systems Research, 22, 2 (2011), 369-388.

16. Benaroch, M. Managing Information Technology Investment Risk: A Real Options Perspective. Journal of Management Information Systems, 19, 2 (2002), 43-84.

17. Carr, N. IT Doesn't Matter. Harvard Business Review, 2003.

18. Melville, N., Kraemer, K., and Gurbaxami, V. Review: Information Technology and Organizational Performance: An Integrative Model of IT Business Value. MIS Quarterly, 28, 2 (2004), 283-322.

19. Sharfman, M., and Fernando, C. Environmental Risk Management and the Cost of Capital. Strategic Management Journal, 29, 6 (2008), 569-592.

20. Strahan, P.E. Borrower risk and the price and nonprice terms of bank loans. working paper, 1999.

21. Dewan, S., Michael, S., and Min, C.-k. Firm Characteristics and Investments in Information Technology: Scale and Scope Effects. Information Systems Research, 9, 3 (1998), 219-232. 
Table 1: Descriptive Statistics

\begin{tabular}{|c|c|c|c|c|}
\hline & Mean & Std. Dev. & Min & Max \\
\hline Loan spread (pts) & 4.16 & 0.91 & 2.35 & 6.63 \\
\hline IT Intensity (percent) & 2.88 & 3.52 & 0.00 & 40.00 \\
\hline Loan Maturity (month) & 3.26 & 0.84 & 0.00 & 5.48 \\
\hline Loan size (MM) & 5.98 & 1.09 & 0.59 & 9.21 \\
\hline Number of lenders & 13.66 & 10.27 & 1.00 & 61.00 \\
\hline Assets (MM) & 8.63 & 1.16 & 5.39 & 12.05 \\
\hline Leverage & 0.29 & 0.16 & 0.00 & 1.09 \\
\hline Growth Potential & 1.83 & 1.40 & 0.60 & 19.15 \\
\hline Profitability & 0.15 & 0.08 & -0.12 & 0.64 \\
\hline $\begin{array}{l}\text { Performance Pricing } \\
\text { (dummy) }\end{array}$ & 0.47 & 0.50 & 0.00 & 1.00 \\
\hline Collateral (dummy) & 0.18 & 0.39 & 0.00 & 1.00 \\
\hline $\begin{array}{l}\text { Number of Financial } \\
\text { Covenants }\end{array}$ & 1.07 & 1.29 & 0.00 & 6.00 \\
\hline Risk & 2.08 & 1.06 & -1.92 & 5.95 \\
\hline Current ratio & 1.49 & 0.78 & 0.20 & 5.38 \\
\hline Accounting quality & 0.20 & 0.36 & 0.00 & 1.94 \\
\hline $\begin{array}{l}\text { Market Concentration } \\
\text { (top3_share) }\end{array}$ & 0.33 & 0.15 & 0.07 & 0.94 \\
\hline Dummy for diversified firm & 0.65 & 0.48 & 0 & 1 \\
\hline
\end{tabular}

$\mathrm{N}=1039$ 
Table 2: Main Results

\begin{tabular}{|c|c|c|c|c|}
\hline & BASE & AUTO & INFOR & TRAN \\
\hline & 1 & 2 & 3 & 4 \\
\hline \multirow[t]{2}{*}{ IT Investment } & $-0.020 * *$ & -0.005 & $-0.023^{*}$ & $-0.037^{*}$ \\
\hline & $(0.007)$ & $(0.013)$ & $(0.009)$ & $(0.015)$ \\
\hline \multirow[t]{2}{*}{ Loan Maturity } & $0.046+$ & 0.044 & $0.079 * *$ & 0.053 \\
\hline & $(0.028)$ & $(0.044)$ & $(0.030)$ & $(0.032)$ \\
\hline \multirow[t]{2}{*}{ Loan Size } & $-0.125 * * *$ & $-0.155^{*}$ & $-0.077^{*}$ & -0.085 \\
\hline & $(0.032)$ & $(0.074)$ & $(0.038)$ & $(0.066)$ \\
\hline \multirow[t]{2}{*}{ Number of Lenders } & $0.005^{*}$ & 0.005 & $0.004+$ & -0.008 \\
\hline & $(0.002)$ & $(0.007)$ & $(0.002)$ & $(0.008)$ \\
\hline \multirow[t]{2}{*}{ Assets } & $-0.206^{* * *}$ & 0.034 & $-0.201 * * *$ & $-0.335 * * *$ \\
\hline & $(0.039)$ & $(0.105)$ & $(0.038)$ & $(0.085)$ \\
\hline \multirow[t]{2}{*}{ Leverage } & $0.861^{* * *}$ & -0.162 & $0.670^{*}$ & $0.738^{* *}$ \\
\hline & $(0.229)$ & $(0.639)$ & $(0.294)$ & $(0.258)$ \\
\hline \multirow[t]{2}{*}{ Growth Potential } & 0.034 & $0.089 * *$ & $-0.177 * * *$ & -0.093 \\
\hline & $(0.042)$ & $(0.030)$ & $(0.053)$ & $(0.059)$ \\
\hline \multirow[t]{2}{*}{ Profitability } & $-2.347 * * *$ & $-4.221 * *$ & $-1.660 * *$ & -0.242 \\
\hline & $(0.597)$ & $(1.238)$ & $(0.511)$ & $(1.092)$ \\
\hline \multirow[t]{2}{*}{ Performance Pricing } & $-0.171 * *$ & $-0.226+$ & $-0.167^{*}$ & 0.057 \\
\hline & $(0.055)$ & $(0.128)$ & $(0.065)$ & $(0.154)$ \\
\hline \multirow[t]{2}{*}{ Collateral } & $0.605 * * *$ & $0.369^{*}$ & $0.683 * * *$ & $0.474+$ \\
\hline & $(0.076)$ & $(0.149)$ & $(0.090)$ & $(0.252)$ \\
\hline \multirow[t]{2}{*}{ Number of Financial Covenants } & $0.144 * * *$ & $0.316^{* * *}$ & $0.096 * *$ & 0.027 \\
\hline & $(0.027)$ & $(0.067)$ & $(0.029)$ & $(0.104)$ \\
\hline \multirow[t]{2}{*}{ Risk } & $-0.120 * *$ & 0.046 & $-0.119 *$ & -0.148 \\
\hline & $(0.045)$ & $(0.143)$ & $(0.057)$ & $(0.117)$ \\
\hline \multirow[t]{2}{*}{ Current Ratio } & 0.054 & -0.055 & 0.049 & 0.076 \\
\hline & $(0.036)$ & $(0.080)$ & $(0.043)$ & $(0.140)$ \\
\hline \multirow[t]{2}{*}{ Accounting Quality } & 0.027 & $0.794^{*}$ & -0.023 & 0.140 \\
\hline & $(0.075)$ & $(0.320)$ & $(0.083)$ & $(0.175)$ \\
\hline $\mathbf{N}$ & 1039 & 235 & 674 & 130 \\
\hline adj. R-square & 0.703 & 0.617 & 0.765 & 0.773 \\
\hline
\end{tabular}

*** $\mathrm{p}<0.001, * * \mathrm{p}<0.01,{ }^{*} \mathrm{p}<0.05,+\mathrm{p}<0.10$

Standard errors are clustered by firms.

Year and industry dummy included. 
Table 3: Post hoc Analysis

\begin{tabular}{|c|c|c|c|c|}
\hline & Low Competition & High Competition & Multi-sector & Single-sector \\
\hline & 1 & 2 & 3 & 4 \\
\hline \multirow[t]{2}{*}{ IT Investment } & -0.011 & $-0.025 * *$ & -0.006 & $-0.043 * * *$ \\
\hline & $(0.013)$ & $(0.009)$ & $(0.007)$ & $(0.008)$ \\
\hline \multirow[t]{2}{*}{ Loan Maturity } & 0.033 & 0.048 & $0.057^{*}$ & 0.046 \\
\hline & $(0.034)$ & $(0.041)$ & $(0.028)$ & $(0.045)$ \\
\hline \multirow[t]{2}{*}{ Loan Size } & -0.052 & $-0.177 * * *$ & $-0.107 * *$ & $-0.113 * *$ \\
\hline & $(0.040)$ & $(0.045)$ & $(0.040)$ & $(0.041)$ \\
\hline \multirow[t]{2}{*}{ Number of Lenders } & 0.004 & 0.005 & $0.005+$ & 0.004 \\
\hline & $(0.003)$ & $(0.003)$ & $(0.003)$ & $(0.004)$ \\
\hline \multirow[t]{2}{*}{ Assets } & $-0.282 * * *$ & $-0.154 * *$ & $-0.109 *$ & $-0.282 * * *$ \\
\hline & $(0.046)$ & $(0.057)$ & $(0.051)$ & $(0.060)$ \\
\hline \multirow[t]{2}{*}{ Leverage } & 0.316 & $1.209 * * *$ & $0.719+$ & $0.545^{*}$ \\
\hline & $(0.302)$ & $(0.333)$ & $(0.366)$ & $(0.248)$ \\
\hline \multirow[t]{2}{*}{ Growth Potential } & $-0.182 * *$ & 0.054 & $-0.079+$ & $0.058 *$ \\
\hline & $(0.062)$ & $(0.034)$ & $(0.042)$ & $(0.028)$ \\
\hline \multirow[t]{2}{*}{ Profitability } & $-1.506^{*}$ & $-2.624 * * *$ & $-1.804 *$ & $-3.254 * * *$ \\
\hline & $(0.691)$ & $(0.771)$ & $(0.717)$ & $(0.724)$ \\
\hline \multirow[t]{2}{*}{ Performance Pricing } & $-0.199 * *$ & $-0.180^{*}$ & $-0.209 * * *$ & -0.041 \\
\hline & $(0.071)$ & $(0.076)$ & $(0.061)$ & $(0.099)$ \\
\hline \multirow[t]{2}{*}{ Collateral } & $0.616^{* * *}$ & $0.616^{* * *}$ & $0.576 * * *$ & $0.534 * * *$ \\
\hline & $(0.093)$ & $(0.114)$ & $(0.105)$ & $(0.111)$ \\
\hline \multirow{2}{*}{$\begin{array}{l}\text { Number of Financial } \\
\text { Covenants }\end{array}$} & $0.111 * *$ & $0.151 * * *$ & $0.190 * * *$ & 0.022 \\
\hline & $(0.033)$ & $(0.039)$ & $(0.034)$ & $(0.040)$ \\
\hline \multirow[t]{2}{*}{ Risk } & -0.072 & -0.101 & -0.110 & -0.052 \\
\hline & $(0.055)$ & $(0.093)$ & $(0.070)$ & $(0.060)$ \\
\hline \multirow[t]{2}{*}{ Current Ratio } & -0.022 & $0.096+$ & $0.144^{*}$ & -0.017 \\
\hline & $(0.062)$ & $(0.052)$ & $(0.055)$ & $(0.046)$ \\
\hline \multirow[t]{2}{*}{ Accounting Quality } & 0.111 & -0.028 & -0.034 & 0.054 \\
\hline & $(0.113)$ & $(0.110)$ & $(0.079)$ & $(0.129)$ \\
\hline $\mathbf{N}$ & 523 & 516 & 677 & 362 \\
\hline adj. R-square & 0.726 & 0.715 & 0.711 & 0.763 \\
\hline
\end{tabular}

$* * * \mathrm{p}<0.001, * * \mathrm{p}<0.01, * \mathrm{p}<0.05,+\mathrm{p}<0.10$

Standard errors are clustered by firms.

Year and industry dummy included. 